\title{
Soil Erosion Modelling at Watershed Level in Indonesia: a Review
}

\author{
Yuari Susanti ${ }^{1, *}, S$ Syafrudin ${ }^{2}$, and Muhammad Helmi $^{3}$ \\ ${ }^{1}$ Master Program in Environmental Science, School of Postgraduate Studies, Diponegoro University, Semarang - Indonesia \\ ${ }^{2}$ Department of Environmental Engineering, Faculty of Engineering, Diponegoro University, Semarang - Indonesia \\ ${ }^{3}$ Department of Oceanografy, Faculty of Fisheries and Marine Sciences, Diponegoro University, Semarang - Indonesia
}

\begin{abstract}
Soil erosion is one of the most serious degradation problems in the world, so in Indonesia. The average level of global soil erosion ranges from 12-15 Ton/ha/yr, or it can be said that there is a surface soil loss of 0.90-0.95 mm of land. While the watershed in Indonesia is 458 in which 60 are critically heavy, 222 critical and 176 potentially critical. An action is needed to reduce erosion rates which is one of the causes of damage to the watershed. Soil erosion modeling is a method used in estimating the amount of soil erosion that occurs in an area. Various models of soil erosion are developed with the aim of producing precise erosion estimates. This study will discuss soil erosion modeling (definition, classification of models and proceed) and a review of erosion assessment models that are widely used in Indonesia (USLE, MUSLE, RUSLE, and SWAT). By knowing each erosion estimation model, hope can be able to choose the right model according to the study to be conducted.
\end{abstract}

Keywords: Erosion modeling; watershed; soil erosion.

\section{Introduction}

Soil erosion is one of the most serious land degradation problems in the world [1]. Soil erosion is a problem that occurs in the watershed ecosystem [2]. Erosion is a process in which granules/parts of the land are released from one place to another by water or wind [3]. While Foster, GR et al (1972) and Kuznetsov, S et al (1998) cites in [4] argue that erosion is a process of loosening, dissolving and disappearing rock material from the earth's surface triggered by the interaction of quite complex factors, for example, natural factors (climate, topography, soil, vegetation) and anthropogenic factors (land preparation systems, soil conservation measures, overgrazing, and deforestation). The average global soil erosion rate ranged from 12-15 Ton/ha/yr or it could be said that there was a surface soil loss of $0.90-0.95 \mathrm{~mm}$ soil [5]. A number that is quite fantastic, so it needs proper environmental management.

Indonesia is a tropical country that has high rainfall. This country has 458 Watersheds where 60 are critically heavy, 222 critical and 176 potentially critical. This is caused by watershed land use changes [6]. Watershed is a land area that has a topographic boundary (ridge) which has the function of receiving and accommodating rainwater, nutrients and sediments which are then channeled through tributaries which empties into lakes and sea [3] Besides that,[7] states that the watershed is a land area which is an integral part of the river and its tributaries, which functions to accommodate, store and drain water originating from rainfall to the lake or to the sea naturally, the boundary on land is topographic separators and boundaries in the sea to water areas that are still affected by land activities. So that it can be concluded that one component that influences the criticality of a watershed is the rate of erosion, so it is important to measure erosion rates to restore watershed conditions.

The causes of erosion can be categorized into two groups, the first is natural factors and the second is anthropogenic factors [8]. In natural erosion, the erosion process is slow and continuous, the rate of soil formation is proportional than the rate of soil loss, it is different from accelerated erosion caused by human behavior. Erosion that occurs due to human intervention is called actual erosion, while erosion which is without the influence of human activities is called potential erosion [9]. Erosion caused by anthropogenic factors generally has a big impact on the sustainability of life, because it brings large materials. We can call it an accelerated erosion, for example, are floods and landslides [10].

Soil erosion has any impact on land quality and water supply[11]. Soil erosion also has a negative impact on human life such as landslides, soil fertility degradation, slope instability, flood disasters, etc $[10,11]$. According to [12], the damage caused by erosion can occur in two different locations, first in the place where erosion occurs, and second in the place where the erosion is carried and deposited. The impacts of erosion in the downstream region are floods, siltation of reservoirs, and river water pollution.

* Corresponding author: happy.january85@gmail.com 
By knowing the many negative impacts of soil erosion, there are many research related to soil erosion such as the causes, impacts, methods, and modeling to determine the erosion rate. This paper is a review of various models of soil erosion assessment that are widely used in Indonesia. The discussion includes definitions, classifications of soil erosion assessment models and reviews of several modeling examples of soil erosion estimation that are widely used in Indonesian research.

\section{Models Types}

Models are representations of states, objects, and events. These representations should be realized in a simple form, by eliminating or minimizing variables that are complicated and not directly related to the model. This simplification is done by a process that is relevant to the actual situation [13]. Soil erosion modeling can provide quantitative results and be consistent in estimating phenomena that occur in various conditions. However, the model is very different in terms of complexity, the process of consideration and data used for model calibration and validation. There is no model suitable for all conditions, there is a model that depends on a number of factors, such as the purpose of use and characteristics of the catchment [14].

Modeling can be grouped into three categories, namely (1) an iconic model, this type of model is a miniature of the real conditions of a situation, (2) an analog model, this model of data is said to have properties and processes that describe real conditions, (3) symbolic models, in this model tend to be identical to mathematical symbols (Surianegara, 1978 in [15]. While [16] argue that there are several models used in predicting the amount of soil erosion in the catchment area, such as physical, conceptual and empirical modeling. The approach to estimating the amount of erosion, namely: laboratory, physical/field, combined, and modeling approaches [17].

Based on the approach, models can be categorized into (1) physical models, analog models, and mathematical models. Besides that, there are also two other types of models; the empirical model and the conceptual model. The empirical model is a model that is based on experiments. While the conceptual model is a model that presents processes in mathematical equations and distinguishes between production functions and traceability functions [18].

The use of models in a study basically has a specific purpose, (1) Forecasting, which includes a warning system and management, forecasting refers to the amount and time to be analyzed, (2) prediction, discussing the magnitude of events and hyphothetical future time, (3) as detection tools for an event with a definite system and controlled output, (4) identification tool in planning problems; for example land management by comparing inputs and outputs in a system, (5) extrapolation and information data, (6) environmental estimates due to changing/increasing levels of human behavior, and (7) basic research in the hydrological process [18].
By selecting the right type of model, it is expected that the study carried out can produce precise and effective results.

\section{Soil Erosion Modelling at Watershed Skale in Indonesia}

Some types of modeling that are often used in predicting soil erosion rates that occur in watershed areas in Indonesia are:

\subsection{USLE (Universal Soil Loss Equation)}

USLE (Universal Soil Loss Equation) is an empirical model used for estimating soil erosion. This model was developed by the USDA (United States Department of Agriculture) in the mid-1960s [16] based on the results of research conducted by Wischeimer and Smith 1978 [19] The model was developed based on the results of long-term erosion in small plots (Wischmeier plots) collected from 49 research locations. The form of erosion that can be predicted by this model is a sheet or groove erosion but cannot estimate sedimentation and sediment yield from eroi trenches, riverbanks and riverbed (Wischmeieir and Smith, 1978 in [12]. The USLE equation is a product of five input factors: soil erodibility, rainfall erosivity, slope length and steepness, cover management, and support practice [20]. Descriptively the model is formulated as follows

$$
\mathrm{A}=\mathrm{R} \times \mathrm{K} \times \mathrm{LS} \times \mathrm{C} \times \mathrm{P}
$$

$\mathrm{A}=$ the estimated soil loss per unit area (ton/ha/year)

$\mathrm{R}=$ the rainfall erosivity factor $(\mathrm{mm} /$ year)

$\mathrm{K}=$ the soil erodibility factor (ton/ha)

$\mathrm{L}=$ the slope-length factor $(\mathrm{m})$

$\mathrm{S}=$ the slope-steepness factor $(\%)$

$\mathrm{C}=$ the cover and management factor, and

$\mathrm{P}=$ the support practices factor

USLE is the most widely used erosion estimation model in the world [16]. Initially, the USLE erosion estimation model was used to design a farming activity, but in the early 1970s, it became very popular as a model for sheet erosion and rill erosion related to the application of soil conservation policies[21]. The use of the USLE model is now not only in agricultural land but in various situations and conditions such as forests, watersheds [20], settlements, grazing, and recreational areas. In Indonesia, this method is contained in Minister of Forestry Regulation Number p.32 / Menhut-II / 2009 Concerning Procedures for Preparing River Basin Forest and Land Rehabilitation Technical Plans (RTKRHLDAS) as a method of calculating Erosion Hazard Level (TBE). Referring to the regulation, it can be said that the model is also used as a basis for policy making for the selection of soil and water conservation techniques to be applied.

Some of the weaknesses of the USLE model include (1) Ineffective when used in conditions outside of the initial development. (2) Adaptation in new environments requires a large investment of time and resources. (3) It 
is not appropriate to use it on a small scale map and can cause over estimation if the researcher subjectivity is excessive [12]. (4) The USLE model does not describe important processes in the hydrological process [21].

The advantages of the USLE model include (1) until now still being accepted and widely applied throughout the world, (2) simple data input with fewer parameters than other models, (3) can be used to determine feasibility soil conservation actions related to land planning and to predict non-point sediment losses in relation to pollution control [22].

Tarigan and Sinukaban (2001) in [22] states that there is a principle that must be considered in the use of this USLE model, that USLE will work well if applied on a plot scale, but if used on a watershed scale can produce excessive predictions, this is due to the effect of sediment filters that are not accommodated. However, USLE will be useful if it is related to the on-effects of erosion, such as the effect of erosion on eroded offshore environments (quality of river water, dam damage due to sedimentation)

\subsection{MUSLE (Modified Universal Soil Loss Equation)}

MUSLE is a model developed to perfect the USLE model. MUSLE (Modified Universal Soil Loss Equation) is able to predict the amount of sedimentation because the rainfall energy factor is converted into an energy runoff factor. Prediction of sediment yield increases because the surface flow is a function of antecedent moisture condition (AMC) as well as rain energy (Zhang, 2008 in [23]). This causes this model more accurate when compared to the original model. The MUSLE was given in the following form [23] :

$$
\begin{aligned}
& \quad \mathrm{Sy}=11,8 \times(\mathrm{Q} \times \mathrm{qp})^{0,56} \times \mathrm{K} \times \mathrm{LS} \times \mathrm{C} \times \mathrm{P} \\
& \mathrm{Sy}=\text { sediment yield (in } \mathrm{t}) \\
& \mathrm{Q}=\text { volume of runoff }(\mathrm{in} \mathrm{m} 3) \\
& \mathrm{qp}=\text { peak flow rate }(\text { in } \mathrm{m} 3 \mathrm{~s}-1) \\
& \mathrm{K}=\text { the soil erodibility factor } \\
& \mathrm{L}=\text { the slope-length factor } \\
& \mathrm{S}=\text { the slope-steepness factor } \\
& \mathrm{C}=\text { the cover and management factor, and } \\
& \mathrm{P}=\text { the support practices factor }
\end{aligned}
$$

The MUSLE model has a lot in common with the original USLE model, so in general it has almost the same characteristics, only one of the advantages of using MUSLE is being able to predict the amount of sediment produced, but calibration must be done to ensure the accuracy of the sediment results obtained and it greatly affects the success of the application of this method [24].

In Indonesia, the MUSLE model has been used in many researches for example by [23], in this research, modifications were made to the MUSLE model by including groove density parameters, the results showed that erosion obtained for groove density 0-3 m/ m2 was still smaller when compared with the MUSLE estimate, which is between 0.16-0.96. However, the modification model shows the effect of the grooves to be greater than the estimated MUSLE if the grooves exceed $3 \mathrm{~m} / \mathrm{m} 2$. So it is recommended to use the groove density coefficient in the MUSLE equation so that the estimates obtained are more precise and planning will work better. The use of other MUSLE models is in research conducted by [25] which examines the prediction of erosion rates that occur in the Lower Watershed Kuranji Watershed. Method MUSLE, vegetation density is calculated here using software Arc.GIS 10.3. and ENVI software 4.5

\subsection{RUSLE (Revised Universal Soil Loss Equation)}

RUSLE is another form of development from USLE. Like USLE, RUSLE is also empirical modeling. Some of the developments contained in the RUSLE model include: (1) There is a correction of the R factor used in calculating rainfall in the USLE method (2) Decreasing topographic parameters from the height of the digital model (DEM). (3) New equation recognition based on the real ratio to interrill erosion that accommodates complex aspects of LS Factor [16].

As the original model, RUSLE also has limitations in its use, (1) RUSLE is only able to predict soil loss caused by sheet erosion excluding trench erosion, (2) The model does not directly predict the sediment yield, (3) RUSLE does not explicitly consider runoff (an important factor in erosion); on the contrary, runoff was included in the R-factor, (4) at the start of RUSLE development, aiming to estimate annual soil loss based on one storm, but its application to a single storm caused a major error [16]. RUSLE is commonly used to predict erosion on an annual scale.

RUSLE erosion model consists of rainfall, soil erodibility, vegetation cover, slope gradient and length, and support practice factors. The RUSLE was given in the following form according to Wischemeier and Smith (1960 and 1978) in [26] :

$$
\mathrm{E}=\mathrm{R} \times \mathrm{K} \times \mathrm{L} \times \mathrm{S} \times \mathrm{C} \times \mathrm{P}
$$

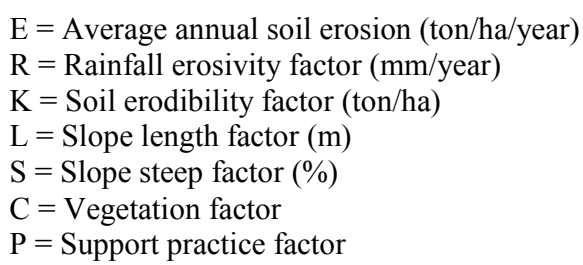

Despite all its limitations, the RUSLE model is still widely used in the world, including in Indonesia. The ease of application and predictions that are quite accurate in estimating the amount of erosion generated to make this model still widely used in research [27], the RUSLE model will produce better and more accurate estimates when combined with the GIS method and remote sensing [26].

\subsection{SWAT (Soil and Water Assesment Tools)}

SWAT (Soil and Water Assessment Tools) is a physical based model developed by the USDA (United States 
Department of Agriculture) to predict the influence of decision making on hydrological characteristics, sedimentation results, nutrients and pollution that occurs in a watershed [28].

The SWAT model was developed by Jeff Arnold in the early 1990s. In 2000, SWAT underwent a fundamental development, in which SWAT could do calculations for the tropics. SWAT is a combination of several ARS developed models and is a further development of the Simulator for Water Resources in Rural Basins (Arsyad 2010) in [29].

SWAT also has the ability to analyze the watershed spatially, where the watershed is divided into subwatersheds or HRU (Hydrologic Response Unit). As for the advantages of this model are as follows: (1) the model is designed to contain ongoing parameters including information on climate, soil properties, topography, plants and land management contained in the watershed, (2) relatively easy data input is available, (3) computerized systems can be made efficiently so that it saves time and costs as well, (4) allows users to evaluate long-term impacts in a watershed [28].

The land phase of the hydrological cycle that is SWAT simulated based on the water balance:

$\mathrm{SWt}=\mathrm{SWo}+\sum_{\mathrm{n}=1}^{\mathrm{t}}($ Rday - Qsurf $-\mathrm{Ea}-\mathrm{W}$ seep-Q-gw $)$

where SWt is the homogeneous water content $(\mathrm{mm})$, SWo is the initial groundwater content at day $1(\mathrm{~mm}), \mathrm{t}$ is the time (days), Rday is the amount of rainfall in day $i$ $(\mathrm{mm})$, Qsurf is the total surface flow in the day $\mathrm{i}(\mathrm{mm})$, $\mathrm{Ea}$ is the amount of evapotranspiration at day $\mathrm{i}(\mathrm{mm})$, Wseep is the amount of water that enters the vadose zone from the soil profile at day $\mathrm{i}(\mathrm{mm})$ and Qgw is the amount of water that is a return flow ( $\mathrm{mm}$ ) That stated $\mathrm{SWt}$ is the homogeneous water content (mm), SWo [29]

Even though it is more complete, this SWAT model has the disadvantage that the model can run if all the parameters needed by this model are properly inputted, even though the output that you want to obtain actually does not require these parameters (Haw, 2014 inside [28])

\section{Result and Disscusion}

Soil erosion is a major cause of land degradation. Soil erosion occurs due to natural factors and anthropogenic factors. The impact of erosion caused by natural factors is less compared to erosion caused by anthropogenic factors.

The impact of erosion can be seen at the location of erosion and at locations where erosion material drifts and settles. So that it can be said that erosion has an economic and environmental impact. Estimating the level of erosion is needed to determine the amount of soil erosion that occurs so that control and prevention can be expected.

Soil erosion can be estimated with several models, such as empirical/statistical/metric, conceptual and physical based. The model discussed in this review is an empirical model (USLE, RUSLE, and MUSLE) while SWAT is a physic based model. These methods were developed by the USDA (United States Department of Agriculture). The selection of the right type of model is the factors that influence the accuracy of the results obtained. Each model has its advantages and disadvantages. USLE is a simple model with easy parameters, so it is widely used in various parts of the world. This model will produce good erosion estimates if done for long-term intervals, 10-20 years. The disadvantage of USLE is cannot measure sedimentation. RUSLE is a refinement of the USLE model, the fundamental difference is in calculating the $\mathrm{R}$ factor, this model will be better if combined with Geographic Information Systems (GIS). RUSLE is usually used for estimating annual erosion. The disadvantage of this model is that it cannot measure the amount of sediment produced. Same with RUSLE, the MUSLE model is the result of the development of USLE, the advantages of this model are being able to show the amount of sedimentation. This is due to changes in the kinetic factor of rainwater into energy runoff. While SWAT is a complete model, it contains parameters of information about climate, soil properties, topography, plants and land management contained in the watershed, has been integrated with computers so that it is efficient to use, but one disadvantage is that the parameters used are quite large and must be filled when the model will be operated, even though the desired results do not actually require these parameters.

\section{Summary and Conclusion}

The soil erosion model is a representation of states, objects, and events in a simple form. In choosing a model, it should be adjusted to several factors, such as goals, parameters available, and various other factors because each model will produce results that are not the same as each other. The problem that is often faced in Indonesia is the difficulty in obtaining the data needed in modeling. In addition, database synergies that have not been integrated among institutions also contribute to this. With the selection of the right model, it is expected that the results will be more accurate so that the output produced can be used in the planning process related to land conservation and efforts to preserve the environment.

\section{Acknowledgement}

The authors express their deepest gratitude to $\mathrm{Mr}$. Syafrudin, and Mr. Muhammad Helmi as a lecturer at Master Program of Environmental Sciences, Diponegoro University who has provided support and guidance. We also thank the anonymous reviewers for their valuable comments to improve the manuscript.

\section{References}

1. A. Aiello, M. Adamo, F. Canora, Remote Sensing 
and GIS to Assess Soil Erosion with RUSLE3D and USPED at River Basin Scale in Southern Italy, Catena 131, 174-185 (2015)

2. P. Nugroho, Model soil water assessment tool (SWAT) for prediksi laju erosi dan sedimentasi sub das Keduang Kabupaten Wonogiri (SWAT model for erosion rate prediction in the Keduang sub catchment, Wonogiri residence), Muhammadiyah Surakarta University (2015)

3. C. Asdak, Hydrology and Management of Watersheds, Yogjakarta: Gadjah Mada University Press (2010)

4. A. Belasri, A. Lakhouili, Estimation of Soil Erosion Risk Using the Universal Soil Loss Equation (USLE) and Geo-Information Technology in Oued El Makhazine Watershed, Morocco, J. Geogr. Inf. Syst. 08(01), 98-107 (2016)

5. C. den Biggelaar, R. Lal, K. Wiebe, V. Breneman, The Global Impact Of Soil Erosion On Productivity. I: Absolute and Relative Erosioninduced Yield Losses, Adv. Agron. 81(03), 1-48 (2003)

6. Suryanto, Watersheds in Indonesia is Critical, Antara News (2013)

7. K.S.N.R. Indonesia, Republic of Indonesia Government Regulation Number 37 of 2012 concerning Management of Watersheds (2012)

8. S.E. Rahim, The Control of Soil Erosion in Environmental Conservation Frameworks, Jakarta: Bumi Aksara (2000)

9. N. Hakim et al., The Basics of Soil Science, Lampung: Penerbit Univeritas Lampung (1986)

10. A.A. Santoso, A.L. Nugraha, A.P. Wijaya, The Erosion Disaster Analysis in Semarang Banyan Watershed Area Using Geographical Information Systems, J. Geod. Undip Oktober 3 (2014)

11. L. Tadesse, K.V. Suryabhagavan, G. Sridhar, G. Legesse, Land use and land cover changes and Soil erosion in Yezat Watershed, North Western Ethiopia, Int. Soil Water Conserv. Res. 5(2), 85-94 (2017)

12. S. Arsyad, Water and Soil Coservation, Bogor: IPB Press (2010)

13. L. Xu, X. Xu, X. Meng, Risk Assessment of Soil Erosion in Different Rainfall Scenarios by RUSLE Model Coupled with Information Diffusion Model: A case study of Bohai Rim, China, Catena 100, 7482 (2013)

14. W.S. Merritt, R.A. Letcher, A.J. Jakeman, A Review of Erosion and Sediment Transport Models, Environ. Model. Softw. 18(8-9), 761-799 (2003)

15. Y. Hidayat, The Application of ANSWERS Model in Predicting Erosion and Surface Flow in Bodong Jaya Watersheds and Way Besar Hulu Watersheds,
West Lampung, Institut Pertanian Bogor (2002)

16. K. Phinzi, N.S. Ngetar, The assessment of waterborne erosion at catchment level using GIS-based RUSLE and remote sensing: A review, Elsevier B.V. (2019)

17. S.E. Rahim, Soil Erosion and Modeling of Estimates in the Dynamics of the Environment in South Sumatra. Palembang, PPLH Lembaga penelitian Universitas Sriwijaya (1995)

18. S.H.Br, Hydrology Analysis, Jakarta: Gramedia Pustaka Utama (1993)

19. R. Rusnam, E.G. Ekaputra, E.M. Sitanggang, Spatial Analysis of the Amount of Erosion Level in Each Land Unit in Batang Kandis Das Sub, J. Tek. Lingkung. 10(2) (2013)

20. R.M.Z. Fauzi, Maryono, Erosion and Sediment Results for Conservation of the Kreo Hulu Watershed, J. Pembang. Wil. Kota 12(4), 429-445 (2016)

21. B. Harsoyo, Review Modeling Hidrologi Das Di Indonesia, J. Sains Teknol. Modif. Cuaca 11(1), 41-47 (2010)

22. T. Vadari, K. Subagyono, N. Sutrisno, Principles, Advantages, and Limitations (2004)

23. M. Rizalihadi, N. Fatimah, L. Nazia, The Modification of Musle's Method in Estimating Erosion Due to the Rill in a DAS, Konferensi Nasional Teknik Sipil 7 (2013)

24. S.H.R. Sadeghi, L. Gholami, A. Khaledi Darvishan, P. Saeidi, A Review of the Application of the MUSLE Model Worldwide, Hydrol. Sci. J., 59(2), 365-375 (2014)

25. S.Y. Nifen A. Triwanda, The Study of Erosion Rate Affected by Vegetation Cover Using Landsat-8 Imagery,. 68-75 (2018)

26. A.Y. Saptari, A. Supriadi, K. Wikantika, S. Darmawan, Remote Sensing Analysis In RUSLE Erosion Estimation 1, Indonesian Journal of Geospatial ITB 4(1), 34-45 (2015)

27. L.M. Risse, M.A. Nearing, J.M. Laflen, A.D. Nicks, Error Assessment in the Universal Soil Loss Equation, Soil Sci. Soc. Am. J. 57(3), 825 (1993)

28. N. Christanto, M.A. Setiawan, A. Nurkholis, S. Istiqomah, J. Sartohadi, M.P. Hadi, The Analysis of Sediment Rate of Upper Serayu Watershed Using the SWAT Model, Maj. Geogr. Indones. 32(1), 50 (2018)

29. I. Staddal, The Surface Flow Analysis and Watershed Analysis When South Sulawesi, Institut Pertanian Bogor (2015) 